\title{
Cognition, functionality and symptoms in patients under home palliative care
}

\author{
Maria Aparecida Scottini ${ }^{1}$ \\ Rachel Duarte Moritz ${ }^{2}$ \\ José Eduardo de Siqueira ${ }^{3}$
}

1. Physician from UFSC, Master of Bioethics, Professor of rheumatology in medicine at Unisul, Florianópolis (SC), Brasil. 2. Physician from UFSC, Master of Medical Sciences, Doctor of Production Engineering, Professor, Department of Medical Clinic, UFSC, Florianópolis (SC), Brasil.

3. Physician from PUCSP, Master of Bioethics, Doctor of Medicine, Professor, Medicine School, PUCPR; Londrina (PR), Brasil.

http://dx.doi.org/10.1590/1806-9282.64.10.922

\section{SUMMARY}

OBJECTIVE: Evaluating the degree of cognition, functionality, presence of symptoms and medications prescribed for patients under palliative home care.

METHOD: Descriptive, cross-sectional study where 55 patients under palliative home care were interviewed. Cognition was evaluated using the Mini-Mental state examination (MM), with patients being separated into two groups: with preserved cognitive ability $(M M \geq 24)$, or altered ( $M M<24)$. The functionality was verified by the Palliative Performance Scale (PPS) and the patients were divided into two groups: PPS $\leq 50$ and PPS $\geq 60$. The symptoms presence was evaluated by ESAS (Edmonton Symptom Assessment System) being considered as mild (ESAS 1-3), moderate (ESAS 4-6) or severe (ESAS 7-10) symptoms. Medications prescribed to control the symptoms were registered. Statistical analysis used Student's t test $(p<0.05)$.

RESULTS: Most of the 55 patients were women (63.6\%), $70.9 \%$ of these had MM> 24, 83.6\% had PPS $<50$ and $78.2 \%$ presented chronic non-neoplastic degenerative disease. There was a significant relationship between PPS $\leq 50$ and $M M \leq 24$. Symptoms were present in $98 \%$ of patients. Asthenia was more frequently reported and was not treated in $67 \%$ of the cases. Severe pain was present in $27.3 \%$ : $46 \%$ without medication and $13 \%$ with medication, if necessary. Most patients with severe dyspnea used oxygen.

CONCLUSIONS: Most of the analysed patients had their cognition preserved, presented low functionality and $98 \%$ reported the presence of symptoms. Severe pain was present in almost $1 / 3$ of the patients without effective treatment. Re-evaluate palliative home care is suggested to optimize patient's quality of life.

KEYWORDS: Palliative Care. Symptom Assessment. Pain. Home Nursing.

\section{INTRODUCTION}

Population aging associated with increased control of chronic-degenerative diseases leads to a systemic commitment of the patient, with greater dependence and consequent loss of quality of life, which leads to an increase in hospital admissions and a high financial expense on healthcare'.

The hospital is not the place for such patients because it increases the risk of infection, causes isolation from the family, and exposure to technological resources that do not bring them benefits'. In this reality, palliative care (PC) is inserted as a necessary measure that provides humanized medical care directed to the sick person and not only to the disease, and whose main goal is the quality of life. WHO estimates that 20 million people every year require PC at the end of life, and that another 20 million need this care in the years before death ${ }^{2}$.

The medical world opinion today is preferably curative/restorative. Consequently, patients with chronic degenerative diseases are often submitted to unnecessary examinations and treatment, with loss of quality of life. These patients, if questioned, would 
not want any kind of invasive therapy. However, the paternalistic view of medicine does not offer these patients the right to exercise their autonomy. On the other hand, the palliative view allows the patient to live as actively as possible, redeem their pending issues and exercise their autonomy ${ }^{3}$. This philosophy is aligned with home treatment, which allows patients to be in their space, to determine their schedules, to live with friends and family, maintaining their daily life routine ${ }^{3}$.

One of the challenges of palliative medicine is to respect the autonomy of the human being, combining their perception and way of living to the disease and death. For the evaluation of the patient's autonomy, the determination of their cognitive status becomes important. The Mini-Mental State Examination (MM) is the most widely used scale for this purpose, with high sensitivity and specificity. In Brazil, there are different versions of the MM, with several cut-off points4. The Almeida version ${ }^{5}$ points out the value of 24 for the cut-off level of the MM as the most suitable for educated elderly people. According to the authors, patients with MM equal or above 24 are with cognitive capacity preserved and able to exercise their autonomy. On the other hand, patients below this value have impaired cognitive ability ${ }^{5}$.

Functionality is an important item for the prognostic evaluation of the patient, and the palliative performance scale (PPS) is used for this purpose ${ }^{6,7}$. It is described that patients with PPS equal to or less than 50 have a prediction of survival around six months and therefore should preferentially receive $\mathrm{PC}^{6,8}$.

Adequate symptom control is one of the anchors of PC and for such, there is a need for a systematic evaluation that allows identification of the physical, psychic and social symptoms of these patients ${ }^{6,9}$. In order to verify an adequate control of the symptoms, the Edmonton Symptom Assessment System (ESAS) $^{10}$ is indicated. The greatest limitation in the use of this scale is that requires the patients communication ability. ${ }^{6,9}$.

Considering the need for PC to be optimized in home care, to encourage respect for patients' autonomy and for healthcare professionals to be adequately trained to control the symptoms of patients under such care, this study was idealized, which aimed to evaluate the degree of cognition, functionality and the presence of symptoms in the patients under home PC of an health plan in the city of Flo- rianópolis. Secondarily, medications used to control the identified symptoms were noted.

\section{METHODS}

Cross-sectional and descriptive study, approved by the Ethics Committee on Research in Human Beings of the University of Southern Santa Catarina (Unisul), under report No. 1,193,273, which evaluated adult patients over 18 years of age enrolled in a private health plan, who were under home PC in the city of Florianópolis, in the year of 2016. In this plan, PC is provided at the request of the attending physician and are carried out by a multi-professional team, through home visits according to the periodicity established by the professional in charge of the case. Inclusion criteria were patients over 18 years old and able to answer questions. At the time of the study, the total number of adult patients under PC was 215 . Sixty-five patients who would receive visits from the researcher in charge were randomly selected. This number was obtained taking into account a sample margin of error of $10 \%$, with a confidence level of $95 \%$ and a maximum percentage of $40 \%$. During the study period, 10 patients were excluded due to death or discharge. Fifty-five patients were evaluated between March and August 2016. The interviews were carried out by the author of this study, who, as an observer, did not appear at any time as a provider of any professional services, such condition being informed to the subjects of the study prior to all interviews. All the patients have signed a informed consent form (TCLE), being guaranteed the secrecy to collected data. Preceding the interview, the researcher made telephone contact with all the patients to know the possibility of accepting participation in the study and to schedule the visits, always carried out at the patient's home. During the visit, after obtaining the TCLE, the questionnaire was applied, which included questions about demographic and clinical data.

For the clinical evaluation of the patients' cognitive status, and indirect evaluation of their autonomy, the MM was administered at the time of the visit. Patients were then separated into two groups, those considered to have preserved cognitive ability, which had a value of $M M \geq 24$, and that of patients who had an $\mathrm{MM}<24$ and, therefore, had altered cognitive ability ${ }^{5}$.

Patients' functionality, an important item for prognostic identification, was verified by the Pallia- 
tive Performance Scale (PPS), which is based on five dimensions: ambulation, activity and evidence of disease, self-care, intake, and conscious level. The score of this scale ranges from 0 to 100, in intervals of 10 points, and the higher the score, the better the performance status ${ }^{6}$. Patients were divided into two groups, with PPS $\leq 50$ and PPS $\geq 60^{8,11}$.

The presence of symptoms was analysed using ESAS10. This scale can evaluate the presence and intensity of nine symptoms: pain, asthenia, nausea, depression, anxiety, drowsiness, appetite changes, dyspnea and malaise. The patients were grouped according to the intensity of each symptom investigated: 0 absent; 1-3 mild; 4-6 moderate and 7-10 severe. It was found in the patients' records whether they were receiving medication for their symptoms and whether they were using oxygen. For statistical analysis, Student's t test (Windows Excel) was used, being considered a $\mathrm{p}<0.05$.

\section{RESULTS}

Analysing the clinical-demographic characteristics of the patients evaluated, 35 (63.6\%) were female and $20(36.4 \%)$ were male, with ages ranging from 25 to 105 years old and a mean of $71.3 \pm 19.3$, and $60 \%$ of the patients were over 71 years old. In relation to schooling, 5 (9.1\%) patients had 0-3 years of schooling, 15 (27.3\%) 4-8 years and 35 (63.6\%) over 8 years of schooling. Regarding mental capacity/MM (Mini-Mental State Exam), 16 (29.1\%) had $\mathrm{MM}<24$ and 39 (70.9\%) $M M \geq 24$. Regarding the PPS functionality, 46 (83.6\%) had PPS $\leq 50$ and 9 (13.4\%) had PPS $\geq 60$. There was a significant relationship between altered cognitive ability $(\mathrm{MM}<24)$ and female $(\mathrm{p}<0.01)$, older age $(p<0.01)$ and low functionality $(p<0.03)$. It should be noted that there were a small number of patients with $P P S \geq 60$. Regarding the diagnosis of the underlying disease, $12(21.8 \%)$ patients had neoplastic disease and 43 (78.2\%) had non-neoplastic chronic-degenerative disease.

Regarding the evaluation of the symptoms, 54 (98\%) of the 55 patients studied reported some type of symptom. Figures 1, 2 and 3 indicate the results regarding the presence of symptoms and the suitability of the prescribed treatment for the control of these symptoms. It can be verified that almost all the patients reported some type of malaise sensation, and the majority, 39 (70.9\%), considered this malaise as mild or moderate. In general, the most prevalent symptoms were asthenia $(\mathrm{n}=37 / 67 \%)$, drowsiness $(n=31 / 56 \%)$, anxiety $(n=30 / 54 \%)$, pain $(n=28 / 51 \%)$, depression $(n=26 / 47 \%)$, dyspnea $(n=25 / 45 \%)$, appetite change $(n=25 / 45 \%)$ and nausea $(n=11 / 20 \%)$. The most prevalent symptom severity was asthenia $(n=20 / 36 \%)$, followed by dyspnea $(n=18 / 33 \%)$ and anxiety $(\mathrm{n}=16 / 29 \%)$. It is noteworthy that $15(27.3 \%)$ patients reported severe pain.

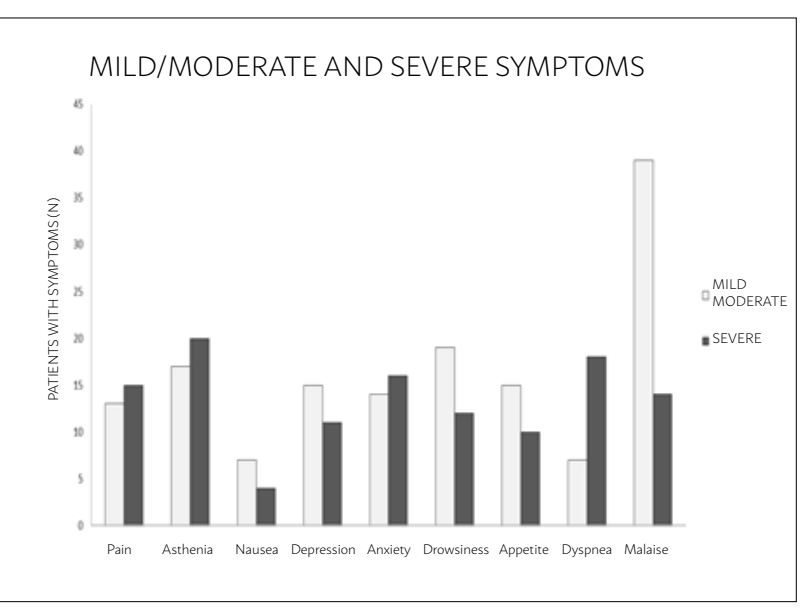

FIGURE 1. Presence of mild/moderate and severe symptoms (ESAS), in relation to the number of patients studied.

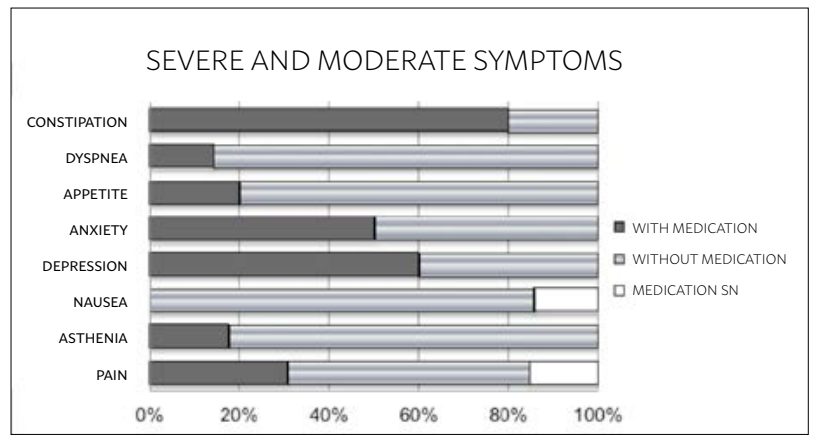

FIGURE 2. Relationship between the presence of mild/moderate symptoms (ESAS) and the prescription of medication to control these symptoms.

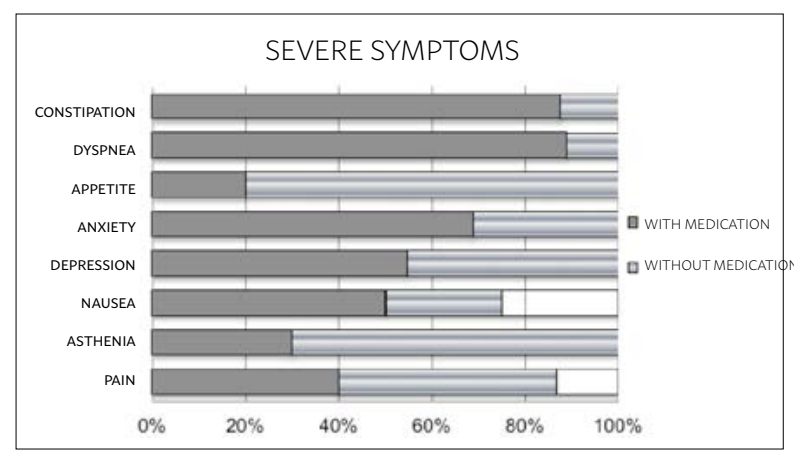

FIGURE 3. Relationship between the presence of severe symptoms (ESAS) and prescription of medication for the control of the symptoms studied. 


\section{DISCUSSION}

In this study, a significant relationship can be observed between the impaired cognitive state $(\mathrm{MM}<24)$ of the patients analysed, female sex, older age and low functionality. These data are within the expected, because with advancing age, worsening functionality and cognitive status are part of aging. Harris et al. ${ }^{8}$ demonstrated that age and sex also contribute to the prognosis, with patients under 65 years old being less likely to die within six months and male patients being more likely to die within six months. It should be noted that the majority of patients analysed (70.9\%) presented $\mathrm{MM} \geq 24$ and, therefore, preservation of cognitive ability, essential for the patient to be able to exercise their autonomy. The MM may present a bias because people may have difficulty performing the test. However, since in this study patients had good education level, this did not occur.

In the sample analysed, there was no difference between the degree of cognition of the patients and the level of education or the diagnosis of the underlying disease. The majority of patients suffered from chronic non-neoplastic degenerative disease, which corroborates the current trend regarding the aging of the population and consequent increase in prevalence of these diseases ${ }^{1}$. It is worth noting that the diagnosis of the disease also interferes with the prognosis. Patients with severe cardiac disease, but with PPS still high, are likely to suffer cardiorespiratory arrest, and patients with certain neoplastic diseases, with any PPS value, have a high probability of death within six months. On the other hand, it is difficult to predict adequate life expectancy for patients with neurological disease or dementia, who may present a very low PPS and no quality of life, but still live for a long time ${ }^{8}$.

Regarding the functionality (PPS) of the patients studied, it can be seen that the majority $(83.6 \%)$ had low functionality and, therefore, an important impairment of their quality of life and social life. A significant correlation between $P P S \leq 50$ and altered cognitive ability was also identified. Therefore, it can be said that the majority of the patients who composed the sample of this study would prefer PC preferentially or exclusively. A study that evaluated patients with non-neoplastic and neoplastic chronic-degenerative diseases pointed out a life expectancy for those with $P P S<50$ around 90 days ${ }^{12}$. Other papers, including only patients with neoplasm, demonstrated an even shorter survival of these patients (34 days) ${ }^{13}$.
Thus, it can be concluded that the lower the PPS value, the shorter the patient's survival ${ }^{8,13}$. It should be emphasized that prognostic evaluation is important for the definition of the treatment, and more specifically the planning of end-of-life care, which should be guided by the values of the patients and their relatives $^{7,13}$.

One of the foundations of PC is symptom control, which allows comfort and quality of life to the patient. At the stage where the patient only needs palliative medical care, events must be predicted for decisions to be shared with the patient/family binomial $^{6,14}$. The control of pain and suffering is considered a fundamental human right, being an important therapeutic competence and ethical responsibility of healthcare professionals ${ }^{\mathbf{1 4}}$. Since 1999 , WHO has recommended as priority the effective control of pain, which is considered the fifth vital $\operatorname{sign}^{2}$. In palliative medicine, there is the definition of "total pain", so that this symptom is evaluated in its physical, emotional, social and spiritual dimension ${ }^{14}$.

The multicentre study Support ${ }^{15}$, conducted in 1995 with 10,000 patients with terminal disease, showed that half of them died with moderate or severe pain, without any analgesic prescription. A recent study with hospitalized patients, not on PC, showed patients with various non-medicated symptoms, including pain ${ }^{16}$. On the other hand, studies with chronic patients under PC demonstrate a good control of symptoms and improvement of the quality of life of these patients ${ }^{17,18}$.

When the patients are under home PC, relatives are responsible for their care, therefore they must be adequately informed about the real condition of their beloved relative and the prognosis of their disease ${ }^{19}$. They also need to receive technical support for care, especially regarding the supply of drugs to control symptoms ${ }^{\mathbf{1 7}}$. This will avoid unnecessary use of care in emergency sectors ${ }^{20}$. Inadequate control of symptoms will lead to patient and family suffering, rendering it unsafe, which will certainly contribute to a difficult mourning, and may lead to conflicts with healthcare professionals and consequent lawsuits ${ }^{\mathbf{1}}$.

A fact observed in this study was the high prevalence of poorly controlled symptoms in the patients analysed, especially regarding the control of mild, moderate or severe pain. The adequate control of pain must ask for individualized prescription, scheduled medication and rescue doses, if necessary. ${ }^{21}$. Unfortunately, in this study only $30 \%$ of the patients were receiving scheduled medication, $45 \%$ of which received 
no drugs to control pain and $20 \%$ received prescription "if necessary". Another poorly controlled symptom in almost $70 \%$ of the patients studied was asthenia. A study that evaluated the symptoms of 168 patients hospitalized in a university hospital showed similar results, indicating poor control of pain reported as moderate. The prescriptions for pain control were predominantly "if necessary", prevailing the use of non-opioid analgesics and weak opioids. In the same study, anxiety was not treated in over $75 \%$ of the patients ${ }^{16}$.

Regarding the evaluation of dyspnea, it was verified that 30 patients were asymptomatic, one of which was submitted to non-invasive ventilation, another was nebulized with bronchodilators and a third one used oxygen associated with nebulization with bronchodilators. Severe dyspnea was reported by 18 patients (32.7\%), of which two patients received no medication to control this symptom. Non-invasive ventilation was provided for three patients with severe dyspnea, and 11 were on oxygen therapy. The use of oxygen was detected in $61.11 \%$ of the patients, with nebulization associated with bronchodilators, the second most commonly prescribed medication for dyspnea control $(\mathrm{n}=12)$.

Thus, a high prevalence of severe dyspnea was observed, in which about $70 \%$ of the patients were being medicated with the administration of oxygen. It is worth noting that the use of oxygen in the final stage of life, and more specifically for the control of dyspnea, is controversial, since, besides the benefit of this medication not being proved, it generates a high cost for the treatment. On the other hand, simple measures like the act of opening a window or connecting a ventilator can decrease the patient's dyspnea by stimulating receptors on the face. It is emphasized that the standard treatment indicated for the control of terminal dyspnea is the use of opioids ${ }^{22}$. This medication was not prescribed for any of the patients with severe dyspnea who participated in this study.

It is worth mentioning that the inadequate control of one symptom may negatively interfere in the development or aggravation of another correlated symptom $^{9,23}$. It is described that, for each symptom spontaneously reported by the patient, nine are no longer communicated $^{16 .}$ For the mentioned reasons, the studies recommend the systematization of the evaluation of the symptoms and their control, the ESAS scale being the most used for this purpose ${ }^{18,19}$. Evaluation and re-evaluation, carried out using the ESAS and PPS scales, should be done at all visits and is essential for the monitoring of symptom control and prognosis, which may vary with the evolution of the disease, serving as a parameter to determine the most appropriate treatment for each moment ${ }^{6,19}$. Studies indicate that the presence of uncontrolled symptoms leads to a deterioration in the quality of life and its control leads to a rapid improvement in patients' well-being, suggesting that the use of checklists can have a fundamental influence on the quality of care ${ }^{23,24}$.

Many symptoms are poorly controlled dued to the doctor's fear of double effect drugs. However, there is an ethical and legal definition regarding the PC to be administered in the final stage of life. The Medical Ethics Code states that in cases of incurable and terminal illness, the physician should offer all PC available, but avoid unnecessary therapies. It is described in Resolution n. 1805/2006 of the Federal Council of Medicine ${ }^{25}$ that, in the terminal stage of serious and incurable diseases, the doctor can suspend treatments and must guarantee the necessary care to relieve the symptoms that lead to the suffering, within an integral care, respecting the patient's wishes. Therefore, the patient has the right to a care that allows them to not suffer, with their symptoms controlled, and as the physician has an ethical duty to provide this type of care ${ }^{26}$. It also influences in the inadequate conduction as to the treatment of patients with terminal illness the lack of technical training of the professionals involved. Brugnolli et al. ${ }^{27}$ showed that, although physicians knew the concept of PC, they did not know how to actually apply it in practice. Other studies show the difficulties of physicians in controlling symptoms, alleviate, treating pain adequately and talking about death ${ }^{26}$. Collins et al., ${ }^{28}$ in their study of "a decade after the Support study," show that the end-of-life quality desired by patients and families should incorporate shared decisions, continuity of care, emotional and spiritual support, and adequate symptom control. These items should be associated with comfort care and the organizational support of healthcare services ${ }^{19}$.

\section{CONCLUSION}

Most patients had preserved cognition, had low functionality and reported the presence of symptoms. Severe pain and major dyspnea were present in almost $1 / 3$ of the patients, not being prescribed effective treatment to them. It is suggested that home PC should be reassessed in order to optimize patients' quality of life. 


\section{RESUMO}

OBJETIVO: Avaliar o grau de cognição, a funcionalidade, a presença de sintomas e as medicações prescritas para pacientes sob cuidados paliativos (CP) domiciliares.

MÉTODO: Estudo transversal, descritivo, em que foram entrevistados 55 pacientes sob CP domiciliares. A cognição foi avaliada pelo miniexame do estado mental (MM), sendo os pacientes separados em dois grupos: com capacidade cognitiva preservada (MM 24 ) ou alterada ( $M M$ <24). A funcionalidade foi verificada pela performance paliativa (PPS), sendo os pacientes divididos em dois grupos: PPS $\leq 50$ e PPS $\geq 60$. A presença de sintomas foi analisada pelo ESAS, sendo considerados sintomas leves (ESAS 1-3), moderados (ESAS 4-6) ou graves (ESAS 7-10). Foram anotadas as medicações prescritas para o controle dos sintomas. Para análise estatística, foi utilizado teste $t$ student's $(p<0,05)$.

RESULTADOS: Dos 55 pacientes entrevistados, a maioria era de mulheres (63,6\%), 70,9\% tinham MM>24, 83,6\% tinham PPS<50 e $78,2 \%$ apresentavam doença crônica degenerativa não neoplásica. Houve relação significante entre PPS $\leq 50$ e MM $\leq 24$. Sintomas estavam presentes em $98 \%$ dos doentes. Astenia foi mais frequentemente apontada, não sendo tratada em $67 \%$ dos casos. Dor grave estava presente em 27,3\%: 46\% sem medicação e 13\% com medicação se necessário. A maioria dos pacientes com dispneia grave usava oxigênio.

CONCLUSÃO: A maioria dos pacientes tinha cognição preservada, apresentava baixa funcionalidade e referia a presença de sintomas. Dor grave estava presente em quase 1/3 dos pacientes, não Ihes sendo prescrito tratamento eficaz. Sugere-se que sejam reavaliados os CP domiciliares com o objetivo da otimização da qualidade da vida dos pacientes.

PALAVRAS-Chave: Cuidados paliativos. Avaliação de sintomas. Dor. Assistência domiciliar.

\section{REFERENCES}

1. Andraos C, Lorenzo C. Sistema suplementar de saúde e internação domiciliar de idosos na perspectiva da bioética crítica. Rev Bioét. 2013;21(3):525-35.

2. Worldwide Palliative Care Alliance, World Health Organization. Global atlas of palliative care at the end of life. 2014. [cited 2015 Jun 22]. Available from: http://www.who.int/cancer/publications/palliative-care-atlas/en

3. Wittmann-Vieira R, Goldim JR. Bioética e cuidados paliativos: tomada de decisões e qualidade de vida. Acta Paul Enferm. 2012;25(3):334-9.

4. Melo DM, Barbosa AJG. O uso do Mini-Exame do Estado Mental em pesquisas com idosos no Brasil: uma revisão sistemática. Ciênc Saúde Coletiva. 2015;20(12):3865-76.

5. Almeida OP. Mini exame do estado mental e o diagnóstico de demência no Brasil. Arq Neuropsiquiatr.1998;56(3B):605-12.

6. Maciel MGS. Avaliação do paciente em cuidados paliativos. In: Carvalho RT, Parsons HA, orgs. Manual de cuidados paliativos ANCP. $2^{a}$ ed. São Paulo: Academia Nacional de Cuidados Paliativos; 2012. p.151-67.

7. Babcock M, Gould Kuntz J, Kowalsky D, Calitri N, Kenny AM. The palliative performance scale predicts three- and six-month survival in older adult patients admitted to the hospital through the emergency department. Palliat Med. 2016;19(10):1087-91.

8. Harris PS, Stalam T, Ache KA, Harrold JE, Craig T, Teno J, et al. Can hospices predict which patients will die within six months? | Palliat Med. 2014;17(8):894-8.

9. Chang VT. Approach to symptom assessment in palliative care. [cited 2018 Dec 3]. Available from: https://www.uptodate.com/contents/approach-to-symptom-assessment-in-palliative-care

10. Paiva CE, Manfredini LL, Paiva BS, Hui D, Bruera E. The Brazilian version of the Edmonton Symptom Assessment System (ESAS) is a feasible, valid and reliable instrument for the measurement of symptoms in advanced cancer patients. PLoS One. 2015;10(7):e0132073.

11. Jansen WJ, Buma S, Gootjes JR, Zuurmond WW, Perez RS, Loer SA. The palliative performance scale applied in high-care residential hospice: a retrospective study. J Palliat Med. 2015;18(1):67-70.

12. Lau F, Maida V, Downing M, Lesperance M, Karlson N, Kuziemsky C. Use of the Palliative Performance Scale (PPS) for end-of-life prognostication in a palliative medicine consultation service. J Pain Symptom Manage. 2009;37(6):965-72.

13. Mei AH, Jin WL, Hwang MK, Meng YC, Seng LC, Yam WH. Value of the Palliative Performance Scale in the prognostication of advanced cancer patients in a tertiary care setting. J Palliat Med. 2013;16(8):887-93.

14. Pessini L, Siqueira JE. Reflexões bioéticas sobre a vida e a morte na UTI. In: Siqueira JE, Zoboli E, Sanches M, Pessini L, org. Bioética clínica. Brasília: CFM/SSB; 2016. p.229-51.

15. The SUPPORT Principal Investigators. A controlled trial to improve care for seriously ill hospitalized patients. The study to understand prognoses and preferences for outcomes and risks of treatments (SUPPORT). JAMA. 1995;274(20):1591-8.

16. Roldi MS, Moritz RD. Evaluation of the symptoms and treatment prescribed to hospitalized patients. Rev Assoc Med Bras. 2016;62(4):307-14.

17. Gomes B, Calanzani N, Higginson II. Benefits and costs of home palliative care compared with usual care for patients with advanced illness and their family caregivers. JAMA. 2014;311(10):1060-1.

18. Singer AE, Goebel JR, Kim YS, Dy SM, Ahluwalia SC, Clifford M, et al. Populations and interventions for palliative and end-of-life care: a systematic review. J Palliat Med. 2016;19(9):995-1008.

19. Institute of Medicine. Dying in America: improving quality and honoring individual preferences near the end of life. Washington: The National Academies Press; 2015. [cited 2018 Jan 5]. Available from: www.nap.edu/ $\mathrm{read} / 18748 / \mathrm{chapter} / 1$.

20. Aslaner MA, Akkaş M, Eroğlu S, Aksu NM, Özmen MM. Admissions of critically ill patients to the ED intensive care unit. Am J Emerg Med. 2015;33(4):501-5

21. Krashin D, Murinova N, Jumelle P, Ballantyne J. Opioid risk assessment in palliative medicine. Expert Opin Drug Saf. 2015;14(7):1023-33.

22. Shreves A, Pour T. Emergency management of dyspnea in dying patients. Emerg Med Pract. 2013;15(5):1-19.

23. Uysal N, Senel G, Karaca S, Kadiogullari N, Koçak N, Oguz G. Symptoms seen in inpatient palliative care and impact of palliative care unit on symptom control. Agri. 2015;27(2):104-10.

24. Williams PD, Graham KM, Storlie DL, Pedace TM, Haeflinger KV, Williams $\mathrm{DD}$, et al. Therapy-related symptom checklist use during treatments at a cancer center. Cancer Nurs. 2013;36(3):245-54.

25. Conselho Federal de Medicina. Resolução CFM n0 1.805, de 28 de dezembro de 2006. Na fase terminal de enfermidades graves e incuráveis é permitido ao médico limitar ou suspender procedimentos e tratamentos que prolonguem a vida do doente, garantindo-lhe os cuidados necessários para aliviar os sintomas que levam ao sofrimento, na perspectiva de uma assistência integral, respeitada a vontade do paciente ou de seu representante legal. [Cited 2014 out 30]. Available from: http://www.portalmedico.org.br/resolucoes/ cfm/2006/1805_2006.htm.

26. Schaefer KG, Chittenden EH, Sullivan AM, Periyakoil VS, Morrison LI, Carey EC, et al. Raising the bar for the care of serious ill patients: results of a national survey to define essential palliative care competencies for medical students and residents. Acad Med. 2014;89(7):1024-31.

27. Brugugnolli ID, Gonsaga RAT, Silva EM. Ética e cuidados paliativos: o que os médicos sabem sobre o assunto? Rev Bioét. 2013;21(3):477-85.

28. Collins LG, Parks SM, Winter $L$. The state of advance care planning: one decade after SUPPORT. Am J Hosp Palliat Care. 2006;23(5):378-84. 